\begin{tabular}{c}
\hline$J C E T, 1$ (1) Maret 2017 ISSN 2549-6379 (Print) ISSN 2549-6387 (Online) \\
JCEBT \\
ONournal of Civil Engineering, Building and Transportation) \\
Available online http://ojs.uma.ac.id/index.php/jcebt \\
\hline
\end{tabular}

\title{
Pengaruh Penambahan Serat Sabut Kelapa (Cocofiber) terhadap Campuran Beton sebagai Peredam Suara
}

\section{Effect of Addition of Coco Fiber (Cocofiber) to Concrete Mixture as Sound Damper}

\author{
Pinter Susanto Zalukhu, Irwan*, Denny Meisandy Hutauruk \\ Program StudiTeknik Sipil, FakultasTeknik, Universitas Medan Area, Indonesia \\ *Coresponding Email: irwan@gmail.com
}

\begin{abstract}
Abstrak
Kepedulian terhadap lingkungan dapat diwujudkan dengan penggunaan material yang berasal dari serat alam sebagai bentuk konservasi energi dan perlindungan lingkungan.Contohnya serat sabut kelapa (cocofiber), Serat Sabut Kelapa adalah salah satu limbah yang belum begitu dimanfaatkan secara maksimal di Indonesia.Padahal jumlah kapasitas serat sabut kelapa yang dihasilkan dari panen kelapa setiap tahunnya di Indonesia cukup besar.Dengan alasan di atas maka perlu dikembangkan penggunaan serat alam yang banyak tersedia di Indonesia ini, agar tidak menjadi limbah yang dibuang begitu saja.Salah satu teknologi dalam memanfaatkan limbah sabut kelapa ini adalah dengan menjadikan serat sabut kelapa menjadi bahan komposit yaitu dengan membuat beton berserat sabut kelapa Oleh sebab itu, perlu dilakukan penelitian mengenai parameter-parameter yang berpengaruh terhadap karakteristik dari beton serat ini. kajian terhadap karakteristik akustik beton serat ini memang sudah pernah dilakukan, tetapi merujuk dari pada penelitian-penelitian sebelumnya, menyarankan untuk meneliti serat sabut kelapa untuk campuran beton dengan persentase serat yang digunakan tidak sama dengan persentase yang pernah digunakan sebelumnya, maka perlu dilakukan penelitian ulang/lanjutan.Karateristik akustik diperoleh dengan cara pengujian akustik dengan menggunakan alat impedance tube. Pada pengujian ini dapat diperoleh nilai koefisien absorbsi dengan menggunakan software pendukung impedance tube yaitu DAQ vactory dan HQ control.
\end{abstract}

Kata Kunci: Absorbs, Akustik, Beton Komposit, Cocofiber, Serat Kelapa

\begin{abstract}
Concern for the environment can be realized with the use of materials derived from natural fibers as a form of energy conservation and environmental protection. For example, coconut coir fiber (cocofiber), Fiber Coconut is one of the waste that has not been fully utilized so in Indonesia. Though the amount of capacity coco fiber produced from coconut harvest each year in Indonesia is quite large. With the above reasons it is necessary to develop the use of natural fibers are widely available in Indonesia, in order not to waste that is thrown away. One of the technologies in use waste coconut husks are to be made of coco fiber composite materials is to make fibrous concrete coco.Therefore, it is necessary to do research on the parameters which affect the characteristics of this fiber-reinforced concrete.Study of the acoustic characteristics of the fiber-reinforced concrete have already been done, but it refers from the previous studies, suggest researching coco fiber for concrete mixes with the percentage of fiber that is used is not the same as the percentage that has been used before, it is necessary to re-research / advanced.Acoustic characteristics obtained by acoustic testing by using an impedance tube. In this test the absorption coefficient can be obtained by using the impedance tube supporting software that vactory DAQ and control $H Q$.
\end{abstract}

Keywords: Absorption, Acoustic, Composite Concrete, Cocofiber, Coconut Fiber

How to Cite: Zalukhu, P.S. Irwan, Hutauruk, D.M. (2017). Pengaruh Penambahan Serat Sabut Kelapa (Cocofiber) terhadap Campuran Beton sebagai Peredam Suara. JCEBT Journal of Civil Engineering, Building and Transportation). 1 (1): 27-36. 
PENDAHULUAN

Kemajuan dan perkembangan teknologi dalam bidang industri konstruksi semakin pesat memacu peningkatan pembangunan di segala sektor kehidupan.Kebutuhan fasilitas perumahan, perhubungan dan industri juga berdampak pada peningkatan kebutuhan bahan-bahan pendukungnya. Salah satu produk yang meningkat tajam adalah beton.

Beton merupakan salah satu bahan konstruksi yang banyak digunakan dalam pelaksanaan struktur bangunan modern. Seiring dengan pesatnya pembangunan di Indonesia, dimana aspek lingkungan harus diperhatikan dengan baik kelestariannya termasuk dalam hal penggunaan pasir dan split yang juga merupakan sumber daya alam yang sebaiknya dibatasi penggunaannya. Teknologi beton yang modern saat ini memungkinkan penggunaan bahan-bahan yang berasal dari alam dapat dibatasi, dan disisi lain bahan limbah dapat dimanfaatkan seoptimal mungkin untuk bahan dasar pembentukan beton.

Kelebihan beton serat adalah, ekonomis (dalam pembuatannya menggunakan bahan dasar yang mudah diperoleh), dapat dibentuk sesuai dengan kebutuhan yang dikehendaki, mampu menerima kuat tekan dengan baik, beton tahan api, tidak busuk atau berkarat, tahan aus, rapat air, awet dan mudah perawatannya. Beton sangat populer banyak dipakai baik untuk strukturstruktur besar maupun kecil.Untuk itu bahan konstruksi ini dianggap sangat penting untuk terus dikembangkan. Salah satu cara untuk mendapatkan material bangunan yang dimaksud di atas adalah dengan cara membuat campuran beton yang ringan, misalnya dengan mencampur limbah serabut kelapa (serat coco fiber).

Berbagai penelitian dan percobaan di bidang beton dilakukan sebagai upaya untuk meningkatkan kualitas beton.Peningkatan mutu beton dapat dilakukan dengan memberikan bahan tambah. Dari beberapa bahan tambah yang ada diantaranya adalah serat coco fiber.

Penelitian ini mencoba mengaplikasikan konsep penggunaan limbah serat cocofiber dalam campuran beton dan juga pengaruhnya terhadap kuat tekan beton serta mampu meredam suara. Pemilihan limbah cocofiber sebagai bahan campuran beton dikarenakan bahan ini mudah didapat, awet, berat massa jenis yang ringan serta mempunyai nilai ekonomis.

Kemajuan dan perkembangan teknologi dalam bidang industri konstruksi semakin pesat memacu peningkatan pembangunan di segala 
sektor kehidupan. Kebutuhan fasilitas perumahan, perhubungan dan industri juga berdampak pada peningkatan kebutuhan bahan-bahan pendukungnya. Salah satu produk yang meningkat tajam adalah beton.

Beton merupakan salah satu bahan konstruksi yang banyak digunakan dalam pelaksanaan struktur bangunan modern. Seiring dengan pesatnya pembangunan di Indonesia, dimana aspek lingkungan harus diperhatikan dengan baik kelestariannya termasuk dalam hal penggunaan pasir dan split yang juga merupakan sumber daya alam yang sebaiknya dibatasi penggunaannya. Teknologi beton yang modern saat ini memungkinkan penggunaan bahan-bahan yang berasal dari alam dapat dibatasi, dan disisi lain bahan limbah dapat dimanfaatkan seoptimal mungkin untuk bahan dasar pembentukan beton.

Kelebihan beton yang lain adalah, ekonomis (dalam pembuatannya menggunakan bahan dasar yang mudah diperoleh), dapat dibentuk sesuai dengan kebutuhan yang dikehendaki, mampu menerima kuat tekan dengan baik, beton tahan api, tidak busuk atau berkarat, tahan aus, rapat air, awet dan mudah perawatannya. Beton sangat populer banyak dipakai baik untuk strukturstruktur besar maupun kecil. Untuk itu bahan konstruksi ini dianggap sangat penting untuk terus dikembangkan. Salah satu cara untuk mendapatkan material bangunan yang dimaksud diatas adalah dengan cara membuat campuran beton yang ringan, misalnya dengan mencampur limbah serabut kelapa (serat coco fiber).

Berbagai penelitian dan percobaan di bidang beton dilakukan sebagai upaya untuk meningkatkan kualitas beton.Peningkatan mutu beton dapat dilakukan dengan memberikan bahan tambah. Dari beberapa bahan tambah yang ada diantaranya adalah serat coco fiber. Penelitian ini mencoba mengaplikasikan konsep penggunaan limbah serat coco fiber dalam campuran beton dan juga pengaruhnya terhadap kuat tekan beton serta mampu meredam suara. Pemilihan limbah cocofiber sebagai bahan campuran beton dikarenakan bahan ini mudah didapat, awet, berat massa jenis yang ringan serta mempunyai nilai ekonomis.

Berbagai penelitian dan percobaan di bidang beton dilakukan sebagai upaya untuk meningkatkan kualitas beton.Peningkatan mutu beton dapat dilakukan dengan memberikan bahan tambah. Dari beberapa bahan tambah yang ada diantaranya adalah serat cocofiber.

Permasalahan utama yang akan diangkat pada penelitian ini adalah bagaimana pengaruh penambahan serat 
coco fiber sebagai bahan tambahan pada campuran beton yang mampu meredam suara.

1. Pada penelitian ini akan dibuat benda uji dengan: Karakteristik yang diteliti adalah Beton yang telah ditambahkan dengan cocofiber mampu meredam suara. Bahan tambahan pada penelitian ini adalah serat cocofiber atau yang kita kenal serat sabut kelapa.

2. Persentase penggunaan serat cocofiber divariasikan dalam beberapa macam, yaitu $0 \%, 1.5 \%, 3 \%, 6 \%$ dari Berat campuran beton yang akan di buat.

3. Untuk pengujian beton peredam suara akan dibuat benda uji berbentuk silinder dengan diameter $10,16 \mathrm{~cm}$ dan tebal $5 \mathrm{~cm}$ sebanyak 2 benda uji/variasi.

4. Untuk serabut cocofiber nya sendiri kita dapatkan dari pabrik pengolah serabut kelapa yang merupakan bahan dasar jok mobil, kesek kaki dan spring bed.

5. Beton dengan bahan tambahan serat cocofiber bertujuan untuk mengetahui seberapa besar pengaruh penambahan serat cocofiber terhadap kuatan beton mampu meredam suara.

\section{METODE PENELITIAN}

Metode yang gunakan untuk penelahan karakteristik akustik serat kelapa ini adalah pendekatan kuantitatif dan kualitatif dari proses learning by doing yang dilakukan terhadap beberapa beton.

Pendekatan kuantitatif dilakukan melalui pengujian dan pengukuran akustik terhadap beberapa jenis matrik yaitu semen. Kemudian dari data-data hasil pengujian dan pengukuran tersebut akan dilakukan analisis kualitatif sebagai usaha untuk menyimpulkan karakter spesifik hingga ditemukan peluang pemanfaatannya sebagai bahan atau konstruksi dasar dari berbagai jenis peralatan. Dalam penelitian ini, menggunakan campuran beton 1: $2: 3$ : 1 (semen: batupecah: pasir: air), yang dicetak pada cetakan pipa PVC berdiameter $10,16 \mathrm{~cm}$ (4 inchi), dan dipotong dengan tinggi $5 \mathrm{~cm}$.

Dengan melakukan kaji ekperimen mengenai karakteristik akustik dari beton ini dapat memperkaya penggunaan atau fungsi dari beton serat sabut kelapa ini.

Beberapa target dari penelitian antara lain

1. Sebagai alternatif baru pembuatan beton dengan menggunakan serat coco fiber sebagai bahan tambahan pada campuran beton dan mampu mengahasilkan beton yang ringan serta kedap suara.

2. Mengetahui parameter yang paling tepat terhadap pengaruh akustik pada 
beton serat ini, terutama terhadap panjang serat, rasio campuran (serat dan matrik), kepadatan beton dan kondisi permukaan bahan.

3. Mengetahui kemampuan dari beton serat kelapa untuk menyerap suara (coefficient of sound absorption) dan mengetahui kemampuannya untuk mereduksi suara (Sound transmission loss).

4. Membuat beton serat sesuai dengan hasil penelitian yang merupakan acuan untuk industri massa.

Metode penelitian yang digunakan adalah eksperimental di laboratorium Dinas Binamarga Provsu khusus untuk pembuatan job mix, sedangkan untuk pengujian kebisingan suara (Noise absorbtion coefficient) dilakukan di Laboratorium Noise \& Vibration Control, Teknik Mesin Universitas Sumatera utara (USU).

Serabut Kelapa yang digunakan adalah serabut kelapa yang di cacah sepanjang $3 \mathrm{~cm}$. Serabut Yang digunakan adalah serabut dalam keadaan kering.Proporsi bahan-bahan penyusun beton ditentukan melalui sebuah perancangan beton. Hal ini dilakukan agar proporsi campuran dapat memenuhi syarat teknis secara ekonomis. Dalam menentukan proporsi campuran dalam penelitian ini berdasarkan pada SK SNI 03-
2834-2000 Tata Cara Pembuatan Rencana Campuran Beton Normal dan diperoleh komposisi campuran yaitu 1: $3: 1$ : 1 (semen : pasir : batupecah : air) dalam perbandingan berat, yang didasarkan Oleh perhitungan Volume benda uji yang mengikuti besar cetakan Yaitu:

$V=\pi r^{\wedge} 2 t$

$\mathrm{V}=3,14 . \llbracket 5,08 \rrbracket \wedge 2.5$

$\mathrm{V}=400,16 \llbracket \mathrm{cm} \rrbracket \wedge 3$

Sedangkan berat isi keseluruhan campuran beton dalam satu cetakan benda uji adalah

$\begin{array}{ll}\text { Semen } & : 500 \mathrm{gr} \\ \text { Pasir } & : 1500 \mathrm{gr} \\ \text { Batu pecah } & : 500 \mathrm{gr} \\ \text { Air } & : 500 \mathrm{gr} \\ + & : 3000 \mathrm{gr}\end{array}$

Variasi persentase serabut kelapa yang digunakan adalah 0\%, 1,5\%, 3\% dan 6\% . Untuk mengetahui nilai serap bising beton maka dibuat benda uji berbentuk silinder dengan diameter 10,16 (4 inchi) $\mathrm{cm}$ dan tinggi $5 \mathrm{~cm}$ masing-masing sebanyak 2 buah untuk benda uji beton normal dan untuk beton dengan penambahan serabut kelapa. Setelah umur beton 24 jam, cetakan silinder dibuka dan mulai dilakukan pengeringan, Sampai betul- betul kering (24 Jam), sehingga benda uji siap untuk di uji di Laboratorium Noise \& Vibration Control, 
Teknik Mesin Universitas Sumatera utara (USU).

Dalam penelitian ini, dapat dibuat diagram alir sebagai berikut :

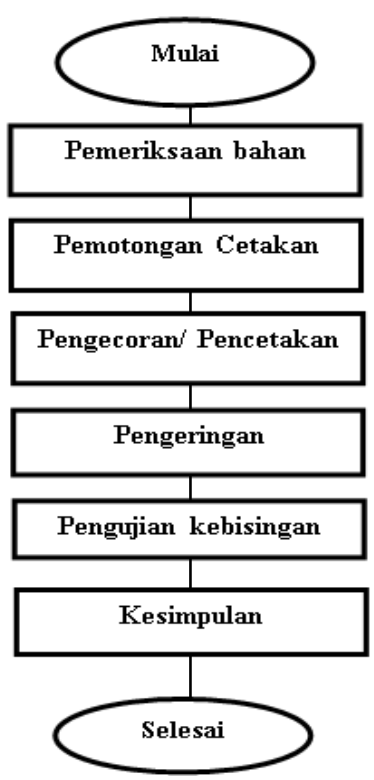

Gambar 1. Diagram Alir

\section{HASIL DAN PEMBAHASAN}

Pengujian serapan bising pada spesimen peredam bunyi dilakukan di laboratorim Noise \& vibration control Teknik Mesin Sumatera Utara dengan alat tube impedance (tabung impedansi satu Mikrofon). Pengujian menggunakan Frekuensi 500 Hz, 1000 Hz, 1500 Hz, dan $2000 \mathrm{~Hz}$.

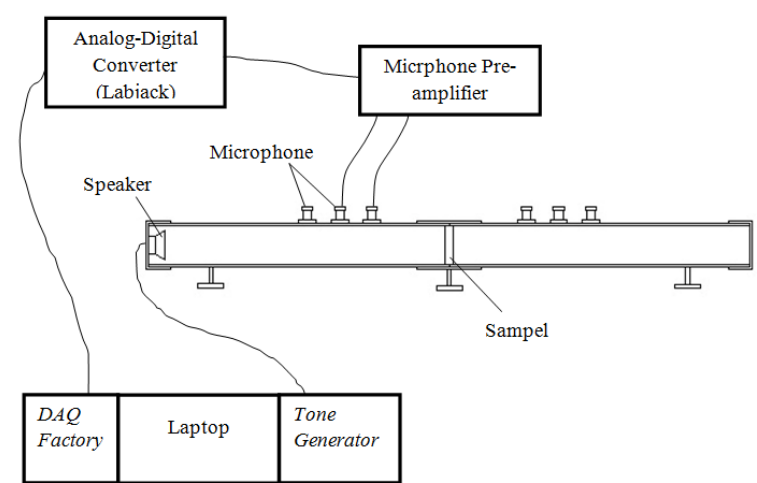

Gambar 2. Skema alat uji peredam suara

\section{Benda uji A}

Tabel

1. Koefisien absorbsi

denganpenambahan serabut kelapa

\begin{tabular}{|c|c|c|c|c|}
\hline & $\begin{array}{l}\text { Spesimen } \\
\text { I }(0 \%)\end{array}$ & $\begin{array}{l}\text { Spesimen } \\
\text { II }(1,5 \%)\end{array}$ & $\begin{array}{l}\text { Spesimen } \\
\text { III }(3 \%)\end{array}$ & $\begin{array}{l}\text { Spesimen } \\
\text { IV }(6 \%)\end{array}$ \\
\hline $\begin{array}{l}\text { f } \\
(\mathrm{Hz})\end{array}$ & $\begin{array}{l}\text { Koef. } \\
\text { Absorsi }\end{array}$ & $\begin{array}{l}\text { Koef. } \\
\text { absorsi }\end{array}$ & $\begin{array}{l}\text { Koef. } \\
\text { absorsi }\end{array}$ & $\begin{array}{l}\text { Koef. } \\
\text { absorsi }\end{array}$ \\
\hline 500 & 0,0324 & 0,2234 & 0,3281 & 0,5911 \\
\hline 1000 & 0,1134 & 0,3237 & 0,3677 & 0,4233 \\
\hline 1500 & 0,1953 & 0,1868 & o,8955 & 0,7513 \\
\hline 2000 & 0,2219 & 0,6608 & 0,5811 & 0,93411 \\
\hline
\end{tabular}

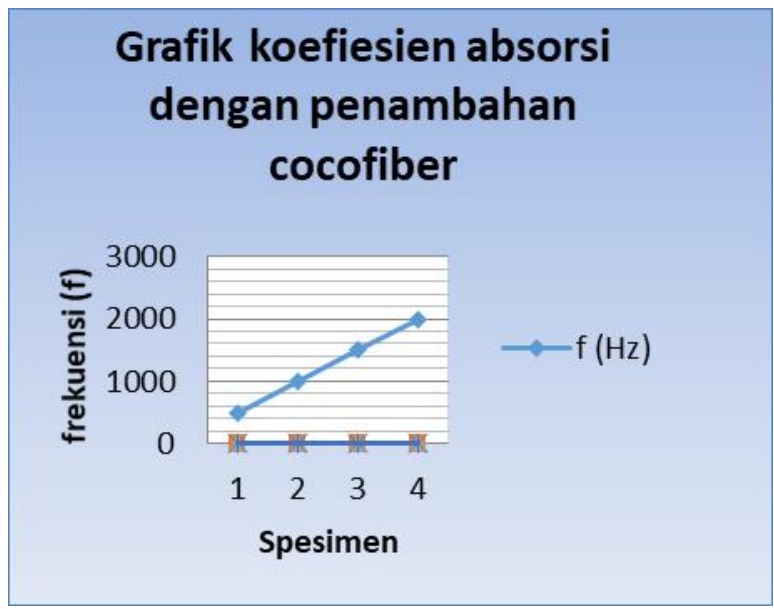

Gambar 3. Grafik koefiesien absorsi dengan penambahan cocofiber

Tabel 2. Serap Bunyi rata-rata untuk setiap penambahan serabut kelapa Sumber: Data hasil penelitian 2016

Variasi serabut Nilai Koefisien Serap Bunyi kelapa/cocofiber Rata - rata

\begin{tabular}{ll}
\hline $0 \%$ & 0,14075 \\
\hline $1,50 \%$ & 0,3237 \\
\hline $3 \%$ & 0,8955 \\
\hline $6 \%$ & 0,93411 \\
\hline
\end{tabular}




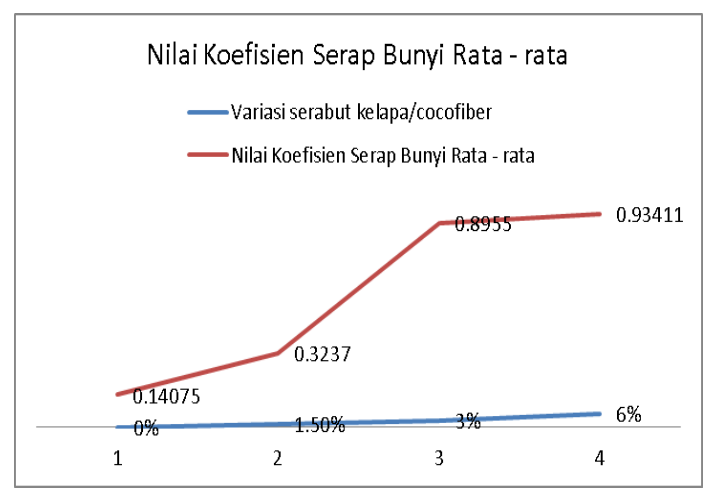

Gambar 4. Nilai Koefisien Serap Bunyi

Rata- rata mengetahui nilai cepat rambat gelombang bunyi pada benda uji A Dengan menggunakan persamaan.

$$
v=f \cdot \alpha
$$

\section{Dimana:}

$\mathrm{V}=$ Nilai cepat rambat gelombang bunyi $f=$ frekuensi

Dari data absorbsi yang telah $\alpha=$ absorbsi

\begin{tabular}{|c|c|c|c|c|c|c|c|c|}
\hline \multirow{2}{*}{$\begin{array}{l}f \\
(\mathrm{~Hz})\end{array}$} & \multicolumn{2}{|c|}{$\begin{array}{l}\text { Spesimen I } \\
(\mathrm{o} \%)\end{array}$} & \multicolumn{2}{|c|}{$\begin{array}{l}\text { Spesimen II } \\
(1,5 \%)\end{array}$} & \multicolumn{2}{|c|}{$\begin{array}{l}\text { Spesimen III } \\
(3 \%)\end{array}$} & \multicolumn{2}{|c|}{$\begin{array}{l}\text { Spesimen IV } \\
(6 \%)\end{array}$} \\
\hline & $\alpha(\mathrm{m})$ & $\mathrm{v}(\mathrm{m} / \mathrm{s})$ & $\alpha(\mathrm{m})$ & $\mathrm{v}(\mathrm{m} / \mathrm{s})$ & $\alpha(\mathrm{m})$ & $\mathrm{v}(\mathrm{m} / \mathrm{s})$ & $\alpha(\mathrm{m})$ & $\mathrm{v}(\mathrm{m} / \mathrm{s})$ \\
\hline 500 & 0,0324 & 16,2 & 0,2234 & 111,7 & 0,3281 & 164,05 & 0,5911 & 295,55 \\
\hline 1000 & 0,1134 & 113,4 & 0,3237 & 323,7 & 0,3677 & 367,7 & 0,4233 & 423,3 \\
\hline 1500 & 0,1953 & 292,95 & 0,1868 & 280,2 & 0,8955 & 1343,25 & 0,7513 & 1126,95 \\
\hline 2000 & 0,2219 & 443,8 & 0,6608 & 1321,6 & 0,5811 & 1162,2 & 0,93411 & 1868,22 \\
\hline
\end{tabular}

Sumber: Data hasil penelitian 2016

Dari hasil penelitian pada benda uji maka, bunyi/ suara yang diserap beton A, menunjukan nilai hasil atau grafik, semakin bertambah (baik). semakin bertambahnya persentase serat sabut kelapa (cocofiber) yang digunakan

\section{Benda Uji B}

Tabel 3.Koefisien absorbsi dengan penambahan serabut kelapa

\begin{tabular}{lllll}
\hline \multirow{2}{*}{$\mathrm{f}(\mathrm{Hz})$} & $\begin{array}{l}\text { Spesimen I } \\
(\mathrm{o} \%)\end{array}$ & Spesimen II $(1,5 \%)$ & Spesimen III $(3 \%)$ & $\begin{array}{l}\text { Spesimen } \\
(6 \%)\end{array}$ \\
\cline { 2 - 5 } & Koef. Absorsi & Koef. Absorsi & Koef.absorsi & Koef.absorsi \\
\hline 500 & 0,0224 & 0,1222 & 0,3881 & 0,4311 \\
\hline 1000 & 0,2134 & 0,3407 & 0,4657 & 0,4333 \\
\hline 1500 & 0,1803 & 0,1859 & 0,5955 & 0,8524 \\
\hline 2000 & 0,2112 & 0,6608 & 0,7811 & 0,9182 \\
\hline
\end{tabular}

Sumber: Data hasil penelitian 2016 


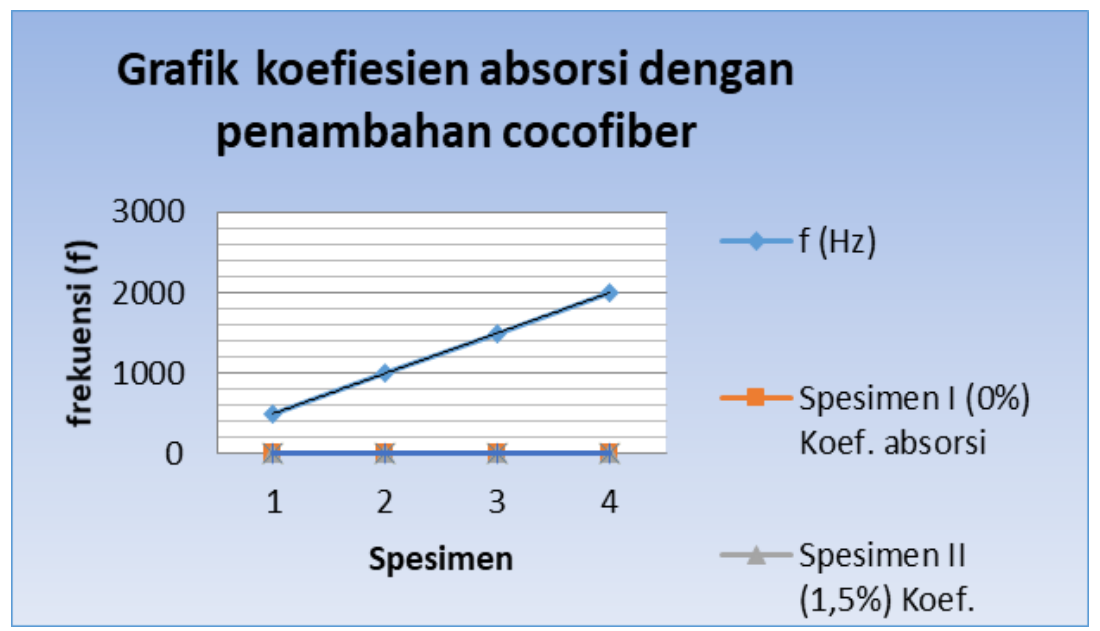

Gambar 5. Grafik koefiesien absorsi dengan penambahan cocofiber

Tabel 4. Serap Bunyi rata-rata untuk setiap penambahan serabut kelapa

\begin{tabular}{ll}
\hline Variasi serabut kelapa/cocofiber & Nilai Koefisien Serap Bunyi Rata - rata \\
\hline $0 \%$ & 0,0224 \\
\hline $1,50 \%$ & 0,3274 \\
\hline $3 \%$ & 0,5576 \\
\hline $6 \%$ & 0,65875
\end{tabular}

Sumber: Data hasil penelitian 2016

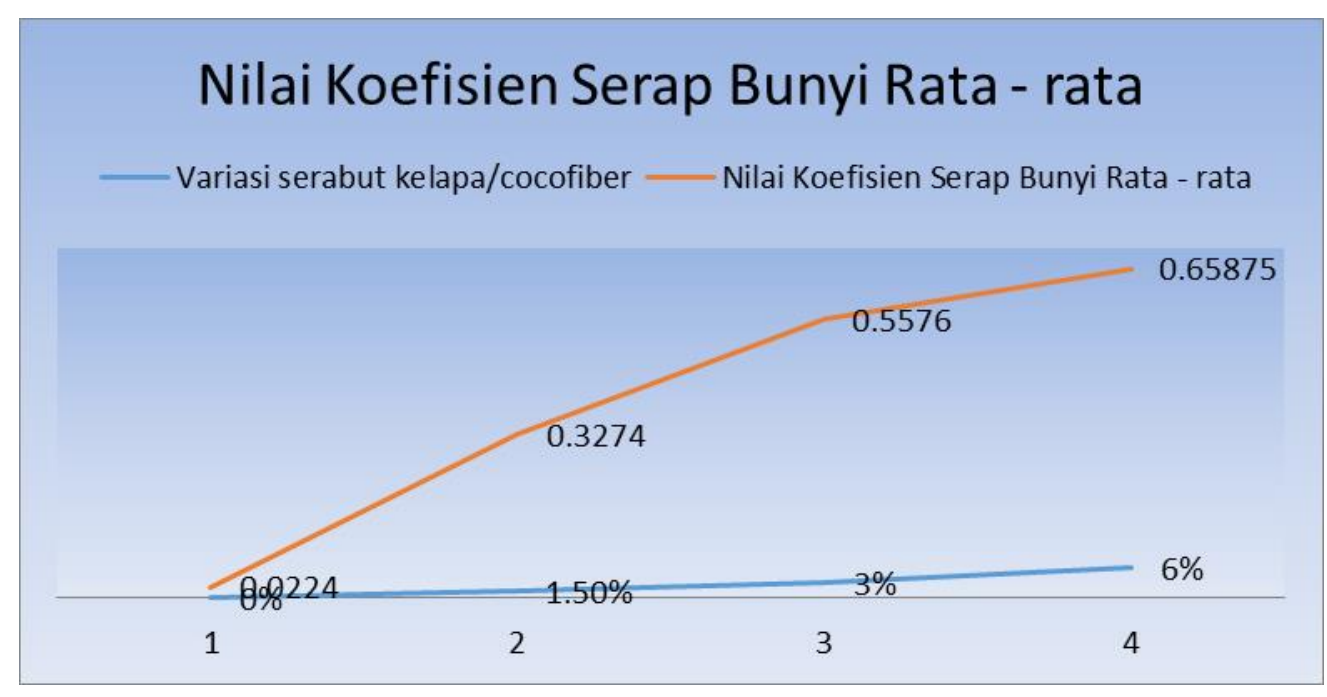

Gambar 6.Grafik nilai Koefisien Serap Bunyi Rata - rata 
Dari data absorbsi yang telah Dimana: didapatkan pada tabel 4.4, maka kita dapat $\quad \mathrm{V}=$ Nilai cepat rambat gelombang bunyi mengetahui nilai cepat rambat gelombang $f=$ frekuensi bunyi pada benda uji B dengan $\alpha=$ absorbsi menggunaka persamaan

$$
v=f \cdot \alpha
$$

Tabel 4.6 Nilai cepat rambat gelombang bunyi.

\begin{tabular}{lllllllll}
\hline \multirow{2}{*}{$\begin{array}{l}\mathrm{f} \\
(\mathrm{Hz})\end{array}$} & $\begin{array}{l}\text { Spesimen I } \\
(\mathrm{o} \%)\end{array}$ & & \multicolumn{3}{c}{ Spesimen II $(1,5 \%)$} & $\begin{array}{l}\text { Spesimen III } \\
(3 \%)\end{array}$ & \multicolumn{2}{c}{ Spesimen IV (6\%) } \\
\cline { 2 - 9 }$(\mathrm{m})$ & $\mathrm{v}(\mathrm{m} / \mathrm{s})$ & $\alpha(\mathrm{m})$ & $\mathrm{v}(\mathrm{m} / \mathrm{s})$ & $\alpha(\mathrm{m})$ & $\mathrm{v}(\mathrm{m} / \mathrm{s})$ & $\alpha(\mathrm{m})$ & $\mathrm{v}(\mathrm{m} / \mathrm{s})$ \\
\hline 500 & 0,0224 & 11,2 & 0,1222 & 61,1 & 0,3083 & 154,15 & 0,4311 & 215,55 \\
\hline 1000 & 0,2134 & 213,4 & 0,3407 & 340,7 & 0,3083 & 308,3 & 0,4333 & 433,3 \\
\hline 1500 & 0,1803 & 270,45 & 0,1859 & 278,85 & 0,3083 & 462,45 & 0,8524 & 1278,6 \\
\hline 2000 & 0,2112 & 422,4 & 0,6608 & 1321,6 & 0,3083 & 616,6 & 0,9182 & 1836,4 \\
\hline
\end{tabular}

Sumber: Data hasil penelitian 2016

Dari hasil penelitian pada benda uji B, Kata “ Absorpsi” sering digunakan oleh menunjukan nilai hasil atau grafik tidak orang-orang dengan mengakaitkan aksi jauh berbeda dengan hasil penelitian pada dari sebuah bunga karang ketika terendam benda uji A, yaitu semakin bertambahnya air. Jika suatu gelombang suara bertemu persentase serat sabut kelapa (cocofiber) atau menumbuk suatu permukaan bahan, yang digunakan maka, bunyi/ suara yang diserap beton semakin bertambah (baik). maka suara tersebut akan dipantulkan,

Dari ke dua data penelitian diatas diserap, dan diteruskan atau menunjukkan bahwa penambahan serat ditransmisikan oleh bahan tersebut. sabut kelapa (cocofiber) dapat Besarnya energi suara yang yang mempengaruhi/bertambahnya nilai serap. dipantulkan, diserap, atau diteruskan Jadi dapat disimpulkan bahwa penggunaan serabut kelapa yang semakin banyak pada campuran beton, nilai serap suaranya semakin baik.

Konsep dari penyerapan bunyi bergantung jenis dan sifat dari bahan atau material tersebut. Pada umumnya bahan yang berpori (porous material) akan menyerap energi suara yang lebih besar dibandingkan dengan jenis bahan lainnya, (Acoustic Absorption) merujuk kepada karena dengan adanya pori-pori tersebut kehilangan energi yang terjadi ketika kedalam material tersebut. Energi suara sebuah gelombang bunyi menabrak dan yang diserap oleh bahan akan dipantulkan dari suatu permukaan benda. dikonversikan menjadi bentuk energi 
lainnya, pada umumnya diubah menjadi energi kalor.

Efisiensi penyerapan bunyi suatu bahan pada frekuensi tertentu dinyatakan oleh koefesien absorbsi bunyi.Koefisien ini dinyatakan dengan $\alpha$ (Alpha), nilai $\alpha$ dapat berada diantara 0 dan 1 pada suatu frekuensi tertentu. Adalah suatu kebiasaan standar untuk membuat daftar nilai koefesien serap bunyi pada wakil frekuensi standar yang meliputi bagian yang paling penting dari jangkauan frekuensi audio, yaitu, $500 \mathrm{~Hz}, 1000 \mathrm{~Hz}, 1500 \mathrm{~Hz}$ dan $2000 \mathrm{~Hz}$.

\section{SIMPULAN}

Nilai koefisien serap bunyi menunjukkan grafik yang semakin meningkat pada setiap penambahan variasi serabut kelapa. Nilai koefisien serap bunyi terendah adalah 0,0324 , Pada frekuensi $500 \mathrm{~Hz}$, sedangkan Nilai koefisien serap bunyi tertinggi adalah 0,93411 pada frekuensi $2000 \mathrm{~Hz}$. Nilai cepat rambat gelombang bunyi terendah 16,2 m/s, Pada frekuensi $500 \mathrm{~Hz}$, sedangkan cepat rambat gelombang bunyi $1868,22 \mathrm{~m} / \mathrm{s}$ pada frekuensi 2000Hz. Dari penelitian ini, disimpulkan bahwa penambahan serat sabut kelapa (cocofiber) dapat mempengaruhi/bertambahnya nilai serap yang semakin baik.

\section{DAFTAR PUSTAKA}

Anonim, (2002). SK SNI 03-2847-2002, Tata Cara Perhitungan Struktur Beton Untuk Bangunan Gedung, Badan Standar Nasional , Jakarta.

Khuriati, A. dkk (2004), "Kajian Kinerja Serapan Bunyi Serabut Kelapa yang dicampur Tepung Kanji dan Serat Sintetik.

Khuriati, A., Komaruddin, E, \& Nur, M. (2006), Disain Peredam Suara Berbahan Dasar Sabut Kelapa dan Pengukuran koefisien Penyerapan bunyinya. Jurnal BERKALA FISIKA, Vol 9 No.1 Januari 2006, hal 15-25 ).

Mediastika, C.E., 2008, "Kajian Kinerja Serapan Bun yi Komposit Jerami Padiyang dicampur Semen".

www.encyclopedia2.thefreedictionary.com, "Absorption Accoustic", pada 2/5/2011.

www.hseclubIndonesia.wordpress.com, "Kebisingan Serta Pengaruhnya Terhadap Kesehatan dan Lingkungan", pada 4/2/2011 